\title{
Buffering assessment of pawpaw (Carica papaya) leaves and stem for fish production in Port Harcourt, Nigeria
}

\author{
O. A. Davies ${ }^{1, *}$, E. Jaja ${ }^{2}$ \\ ${ }^{1}$ Department of Fisheries and Aquatic Environment, \\ Rivers State University of Science and Technology, Port Harcourt, Nigeria \\ ${ }^{2}$ Department of Applied and Environmental Biology, \\ Rivers State University of Science and Technology, Port Harcourt, Nigeria \\ *E-mail address: daviesonome@yahoo.com
}

\begin{abstract}
Organic materials are alternatives to chemicals for safe and healthy fish production. This study aimed at comparing the buffer efficiency of pawpaw leaves and stem with calcium carbonate on acidic borehole water at different dosages for aquaculture. Forty-eight, 25-litres shaded plastic tanks of three replicates per treatment were used. The tanks were 20 litres filled with experimental water ( $\mathrm{pH}$ 4.7). There were sixteen treatment ( $\mathrm{T}$ ) levels ( $\mathrm{T} 0$ to $\mathrm{T} 16)$. $\mathrm{T} 1$ to $\mathrm{T} 15$ were classified into three groups of three dosage levels (G) (2.4g [G1], 6g [G2] and 12g [G3]) per pawpaw leaves and stem [dried leaves (DL), fresh leaves (FL), dried stem (DS) and fresh stem (FS)] and calcium carbonate (CA). $\mathrm{pH}$ and temperature were monitored once daily while dissolved oxygen, alkalinity and calcium were measured weekly for thirty-one (31) days using standard method. Data were analyzed for analysis of variance, Duncan Multiple Range and descriptive statistics. At the end of the study period, the minimum (4.7) and maximum (7.30) $\mathrm{pH}$ were recorded in $\mathrm{T} 0$ and $\mathrm{T} 11$ respectively. Water $\mathrm{pH}$ progressively increased from Day 1 to Day 31 in all the treatment levels. The order of buffer efficiency of pawpaw leaves and stem at the end of the experiment in all the treatment groups was FS $<$ DS $<$ FL $<$ DL. pH values ranged between $6.41 \pm 0.01$ (T4) and $7.03 \pm 0.02$ (T11) on Day 28 and were within the acceptable range of 6.5-9.0. This study therefore suggests the use of DL, FL, DS and FS for fish production. It is free of cost and safe for fish production and human consumption.
\end{abstract}

Keywords: Biotechnology; organic buffer; efficiency; pawpaw plant; $\mathrm{pH}$

\section{INTRODUCTION}

Biotechnology is a growing technology in recent times. United Nations (1992) defined it as any technological application that uses biological systems, living organisms, or derivatives thereof, to make or modify products or processes for specific use. The pawpaw plant (Carica papaya) is widespread throughout tropical Africa and being cultivated for food and medicinal purposes. The rind and pulp of its unripe fruits had been used as antimalarial medicine (Bhat and Surolia, 2001) and its leaf extraction as an antioxidant (Srikanth et al., 2010), anticancer and immunomodulatory (Otsuki et al., 2010) and antimicrobial (Garba and Okeniyi, 2012). The root extracts of C. papaya has been used as antibacterial (Doughari et 
al., 2007). The unripe pulp of C. papaya contains $24.86 \mathrm{mg} / 100 \mathrm{~g}$ of calcium, $23.54 \mathrm{mg} / 100 \mathrm{~g}$ of magnesium and $14.12 \%$ of total ash (Oloyede, 2005). Its leaves and peels are made up of $154 \pm 1.2 \mathrm{~g} / \mathrm{kg} \mathrm{DM}$ and $154 \pm 3.4 \mathrm{~g} / \mathrm{kg} \mathrm{DM}$ of ash (Munguti et al., 2006). The leaves of five morphotypes of pawpaw contain $267.2 \mathrm{mg} / 100 \mathrm{~g}$ and $366.70 \mathrm{mg} / 100 \mathrm{~g}$ of calcium, and $1.43 \%$ and $2.25 \%$ ash (Nwofia et al., 2012). The root extracts contains saponins, alkaloids, tannins, glycosides and phenols which have antibiotic potency (Doughari et al., 2007).

Profitability of aquaculture in Port Harcourt is constrained by low water and sediment $\mathrm{pH}$. This has contributed to $95 \%$ closure of fish farms in Port Harcourt (Okpaku, 2011). Concerted effort has been made to reduce cost of production and eliminate the use of synthetic chemicals in fish production for safe and healthy food. Organic materials are alternatives to chemicals. A buffer is like a chemical cushion that neutralizes acids or bases when added to water. It can be natural (carbon dioxide when dissolved in water forms carbonic acid buffer, minerals such as calcium and magnesium which comes from rocks like limestone) or manmade (Clean Water Team [CWT), 2004). The use of whole and/or parts of plants and animals as organic (natural) buffer is a new technology in organic aquaculture. Davies et al (2012) reported the buffering efficiency of plantain plant (Musa acuminata) parts and calcium carbonate on acidic borehole water for fish production in Port Harcourt, Nigeria. The study revealed that the buffering efficiency of dried stem was significantly higher than that of dried leaves $(\mathrm{P}<0.05)$. Dried stem and leaves of plantain plant competed favourably with the buffering efficiency of $\mathrm{CaCO}_{3}$. That study further suggested the use of dried stem and leaves of plantain plant as organic sources of buffer for fish production. It is free of cost and safe for fish production and human consumption.

$\mathrm{pH}$ (puissance of d'Hydrogene meaning strength of the hydrogen) is defined as the negative log of the hydrogen ion concentration. $\mathrm{pH}$ scale is logarithmic measurement of the concentration of hydrogen ions and it goes from $0-14$. For each whole number increase (that is, 1 to 2), the hydrogen ion concentration increases ten-fold or times. $\mathrm{pH}$ affects fish health in many ways. Each species of fish has its own very narrow range of $\mathrm{pH}$ preference and levels outside of this range will cause health problem (FishDoc, 2010). For examples, catfish and tilapia prefer a range of 6 to 8 (Water Research Commission, 2010). Catfish and tilapia are the major cultured fish in Nigeria. Pawpaw plant is abundant in Port Harcourt and Nigeria as whole and has only been used for food and medicinal importance but not as organic buffer to the best of my knowledge. This study therefore aims at comparing the buffering efficiency of pawpaw plant parts with calcium carbonate on acidic borehole water at different dosages.

\section{MATERIALS AND METHODS}

The study was conducted at Roone Fish Farm, Abuloma, Port Harcourt, Rivers State, Nigeria. Forty-eight (48) 25-litres shaded plastic tanks of three replicates per treatment were used for this study. Duration of the study was thirty-one (31) days. The tanks were placed on outdoor concrete tanks and 20-litres filled with acidic borehole water ( $\mathrm{pH} \mathrm{4.7).} \mathrm{They} \mathrm{were}$ kept open throughout the study. $\mathrm{pH}$ was taken in-situ using Hanna pHep meter (H19127). The $\mathrm{pH}$ meter electrode was inserted into the water up to the marked point $(3.5 \mathrm{~cm})$ on the meter for two (2) minutes. The meter was agitated slightly at interval so that the probe (electrode) could read the $\mathrm{pH}$. The $\mathrm{pH}$ value was taken once the displaced value was stable for few seconds. Temperature was measured in-situ with the use of mercury-in-glass thermometer $\left({ }^{\circ} \mathrm{C}\right)$. The thermometer was inserted into the experimental water up to a depth of $2 \mathrm{~cm}$ for 30 seconds. The temperature reading was taken when the mercury level was stable. 
Dissolved oxygen (DO) $(\mathrm{mg} / \mathrm{L})$ was measured using Freshwater Aquaculture Testing (Aquacare 2000.6 Para test) by using $75 \mathrm{ml}$ of the experimental water. The DO bottle mouth was blocked by the finger (thumb) and dipped into the experimental tank at a depth of 30-40 $\mathrm{cm}$. Water was slowly allowed into it, filled and tightly covered to avoid air bubbles into the bottle. Three drops of Reagent 1were added, followed by 3 drops of Reagent 2 and shaken by inverting the bottle for several times. The sample turned brownish yellow forming a thick precipitate. It was left for 30 seconds to allow the precipitate to settle. After this time duration, 3 drops of Reagent 3 was added and shaken until the precipitate dissolved completely. The sample was divided into two equal parts and one part was used to test for DO value by means of titration. Titration was done by adding Titrant Solution 4, drop by drop and whirled until the brownish yellow colour disappeared. The number of Titrant Solution 4 was counted and divided by 2 to obtain the DO value in $\mathrm{mg} / \mathrm{L}$ (ppm). Oxygen contents and interpretation for this Para test is shown in Table 1. The other part of the sample was used for countercheck. The alkalinity $(\mathrm{mg} / \mathrm{L})$ was measured by Aquacare 2000.3 Para test. One (1) drop of indicator B was added to $5 \mathrm{ml}$ of the experimental water and mixed well. The sample water turned greenish-blue. Titrant Solution A was added, drop by drop and whirled test vessel gently after each drop until the solution changed to lavender-gray (right before end point). One (1) more drop was added into the solution to turn pink. The number of drops used from the Titrant Solution A was multiplied by 17 to give the total alkalinity level in $\mathrm{mg} / \mathrm{L}$. Calcium $(\mathrm{mg} / \mathrm{L})$ by Aquacare 2000.10 Para tests were done using $5 \mathrm{ml}$ of the borehole water. Four (4) drops of reagent 1 was added to the sample water, shaken and a level spoonful of powder 2 was further added and shaken to dissolve. The solution turned pink. Titrant Solution 3 was slowly added into the solution while swirling lightly until the pink solution turned blue. The number of drops used for titration was multiplied by 20 to obtain calcium value in $\mathrm{mg} / \mathrm{L}$

The pawpaw plant parts were manually harvested with cutlass and cleaned to devoid of foreign matters (stones, dust and plant materials). Each part of this plant was divided into two groups (dried and wet). The plant parts for drying were sun-dried for 5-7 days following the method adopted by Davies and Mohammed (2011). Dried and wet plant parts were weighed using electronic scale TH-500 (500g X 0.1g). The two groups of plant parts were used as one piece (uncrushed form). Calcium carbonate was in powdered form (from the manufactured company).

Table 1. Dissolved contents and interpretation.

\begin{tabular}{cc}
\hline Dissolved oxygen (mg/L) & Interpretation \\
\hline 0.5 & Dangerous, insufficient fish \\
2.0 & Serious, for robust fish \\
4.0 & Sufficient oxygen supply for all kinds of fish \\
$>5.0$ & Good, plenty of oxygen for all kinds of fish \\
\hline Source: Aquacare 2000.6, PARA dissolved Oxygen Test Range $0-15 \mathrm{mg} / \mathrm{L}(\mathrm{ppm})$
\end{tabular}

There were sixteen (16) treatment levels (T0 to T15). T1 to T15 were grouped into three groups based on dosage levels $(2.4 \mathrm{~g}, 6 \mathrm{~g}$ and $12 \mathrm{~g}$ ) per pawpaw plant parts [dried leaves (DL), fresh leaves (FL), dried stem (DS) and fresh stem (FS)] and calcium carbonate (CA) as 
shown in Table 2. T0 was the control treatment. Viveen et al. (1986) guideline (Table 3 ) for application of liming materials was adopted as a guide for the amount of organic buffer (pawpaw plant parts) used. That guideline further stated that 'if the selected rate is adequate, $\mathrm{pH}$ will be 6.5 after two (2) to four (4) weeks'. This study used the suggested amount of liming material for sandy pond as a guide to estimate the quantity of the used organic buffer as shown below:

Calculation for amount of plantain plant parts used $900 \mathrm{~kg}$ of organic buffer $=1 \times 10^{7} \mathrm{~m}^{3}$ of water of $\mathrm{pH} 5.6-6.0$ $0.009 \mathrm{~kg}(9 \mathrm{~g})$ of organic buffer $=100 \mathrm{~L}$ of water of $\mathrm{pH}$ 5.6-6.0 Therefore, $9 \mathrm{~g} \mathrm{X} 3$ (factor) was assumed for $100 \mathrm{~L}$ of water of $\mathrm{pH}$ below 5.1

The $\mathrm{pH}$ and temperature were monitored once daily while dissolved oxygen (DO), calcium and alkalinity were measured weekly for 31 days using the above described methods for the duration of study. The measurement of these water quality parameters were restricted to 31 days adopting Viveen et al. (1986) recommendation of minimum duration of 14 days to obtain pH 6.5 if selected rate of liming materials is used. Data were subjected to analysis of variance (ANOVA), Duncan Multiple Range and descriptive statistics using SAS (2003) statistical package.

Table 2. Composition of experimental tanks.

\begin{tabular}{|c|c|c|c|}
\hline Treatment (T) & Composition of treatment & Group $(G) /$ & Dosage \\
\hline T0 & Borehole water (BHW) only & & \\
\hline $\mathrm{T} 1$ & $\mathrm{BHW}+2.4 \mathrm{~g} \mathrm{DL}$ & 1 & $(2.4 \mathrm{~g})$ \\
\hline $\mathrm{T} 2$ & $\mathrm{BHW}+2.4 \mathrm{~g} \mathrm{FL}$ & & \\
\hline $\mathrm{T} 3$ & $\mathrm{BHW}+2.4 \mathrm{~g} \mathrm{DS}$ & & \\
\hline $\mathrm{T} 4$ & $\mathrm{BHW}+2.4 \mathrm{~g} \mathrm{FS}$ & & \\
\hline T5 & $\mathrm{BHW}+2.4 \mathrm{~g} \mathrm{CA}$ & & \\
\hline T6 & BHW + 6g DL & 2 & $(6 \mathrm{~g})$ \\
\hline $\mathrm{T} 7$ & $\mathrm{BHW}+6 \mathrm{~g} \mathrm{FL}$ & & \\
\hline $\mathrm{T} 8$ & $\mathrm{BHW}+6 \mathrm{~g}$ DS & & \\
\hline T9 & $\mathrm{BHW}+6 \mathrm{~g} \mathrm{FS}$ & & \\
\hline $\mathrm{T} 10$ & $\mathrm{BHW}+6 \mathrm{~g} \mathrm{CA}$ & & \\
\hline $\mathrm{T} 11$ & $\mathrm{BHW}+12 \mathrm{~g} \mathrm{DL}$ & 3 & $(12 \mathrm{~g})$ \\
\hline $\mathrm{T} 12$ & $\mathrm{BHW}+12 \mathrm{~g} \mathrm{FL}$ & & \\
\hline $\mathrm{T} 13$ & $\mathrm{BHW}+12 \mathrm{~g}$ DS & & \\
\hline $\mathrm{T} 14$ & $\mathrm{BHW}+12 \mathrm{~g} \mathrm{FW}$ & & \\
\hline $\mathrm{T} 15$ & $\mathrm{BHW}+12 \mathrm{~g} \mathrm{CA}$ & & \\
\hline
\end{tabular}


Table 3. Application guideline for liming material in $\mathrm{kg} / \mathrm{hectare}$.

\begin{tabular}{cccc}
\hline pH of pond bottom & Heavy loamy or clays & Sandy loam & Sand \\
\hline $5.1-5.5$ & 5400 & 3600 & 1800 \\
$5.6-6.0$ & 3600 & 1800 & 900 \\
$6.1-6.5$ & 1800 & 1800 & 0 \\
\hline
\end{tabular}

Source: Viveen et al. (1986)

\section{RESULTS AND DISCUSSION}

Water quality in fish ponds is affected by the interaction of several chemical components. Alkalinity and $\mathrm{pH}$ interact and can have profound effects on pond productivity, level of stress, fish health, oxygen availability and toxicity of ammonia as well as that of certain metals (FishDoc, 2010). pH concentration fluctuates or cycles daily while alkalinity is relatively stable but can change over time usually weeks to months, depending on the $\mathrm{pH}$ or mineral content of watershed and bottom soils. The $\mathrm{pH}$ of the experimental water increased from 4.70 (minimum, Day 1) to 5.01 (maximum, Day 31) in T0 (Fig. 1).

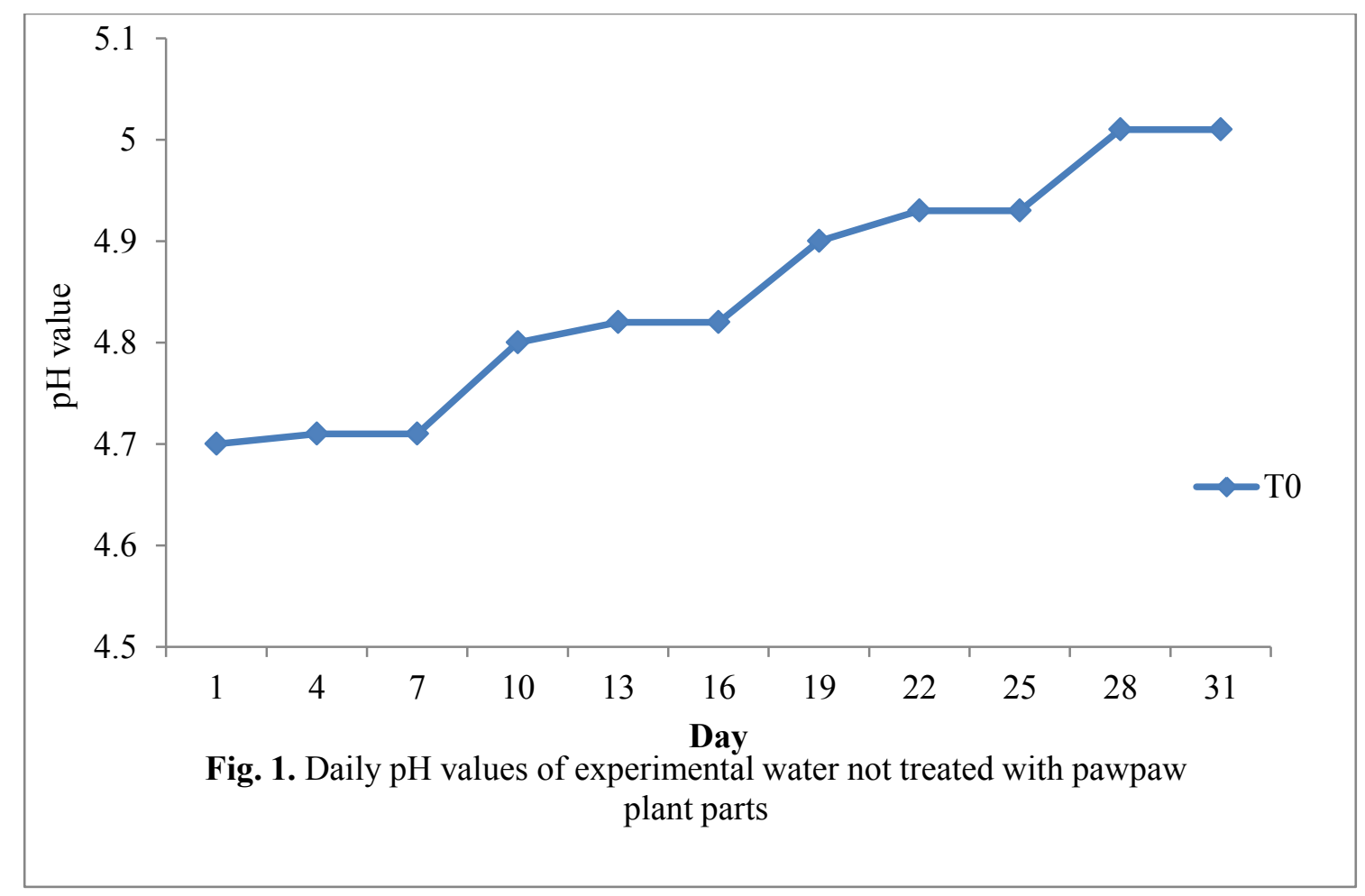

The recorded increasing $\mathrm{pH}$ over the time could be attributed to diffusion of air containing oxygen gas into the experimental water. Dissolved oxygen is directly proportionate to $\mathrm{pH}$. This treatment type is not dependable for fish production (especially intensive and large scale production) based on Viveen et al. (1986) recommendation of 
minimum duration of 14 days to obtain $\mathrm{pH} 6.5$ if selected rate of liming materials is used. Buffer agents are therefore required to speed up the process for increased fish production especially fingerling production. The $\mathrm{pH}$ progressively increased in all treatments from Day 1 to Day 31 (Table 4). Its values ranged from 4.70 (minimum, on Day 1 for all treatments) to 7.22 (maximum on Day 31 in T15). The change of $\mathrm{pH}$ by 1 unit indicated that the hydrogen ion concentration increased ten times. There were ten-fold increases in the $\mathrm{pH}$ of the experimental water from Day 10 for DL and CA and only for CA on Day 4 while DL, FL, DS, FS and CA. from Day 16 in Group 1 (G1) treatments. This signified that the buffer materials were potent. For G2, ten-fold increases were observed from Day 10 for DL and CA and Day 16 for DL, FL, DS, FS and CA. While for G3, they were observed from Day 7 for DL, FL, DS and Ca and Day 10 for DL, FL, DS, FS and CA. In the G1 treatments (2.4 g), pH of water increased from Day 1 to Day 31 in all the treatment levels (Fig. 2). There were no significant differences $(\mathrm{P}<0.05)$ in the buffering efficiency of dried leaves (DL) (T1) and calcium (CA) (T5) throughout the study period (Table 4). The differences among the treatment types were not more than 0.5 units. IJC (1977) stated that waste discharges should not alter the ambient $\mathrm{pH}$ by more than $0.5 \mathrm{pH}$ units so it can be said that there is significant difference in the treatment types if the difference is more than $0.5 \mathrm{pH}$ units.

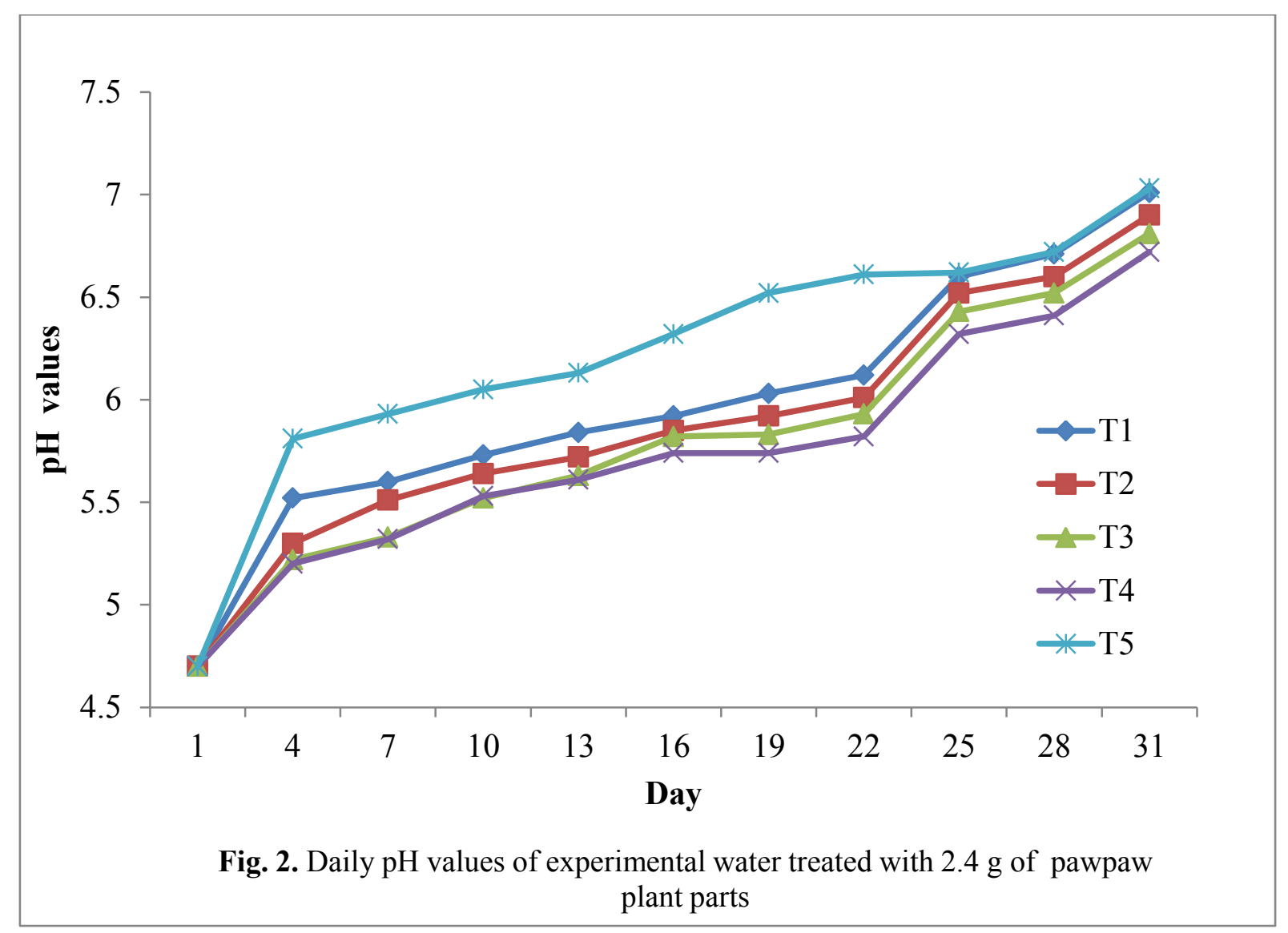

According to SWRCB (2004), narrow pH range favours many chemical reactions inside aquatic organisms (cellular metabolism) that are necessary for their survival and growth. However, T5 attained the acceptable value $(\mathrm{pH}$ 6.52) for fish production on Day 19 while $\mathrm{T} 1$ recorded $\mathrm{pH}$ value of 6.60 on Day 25. 


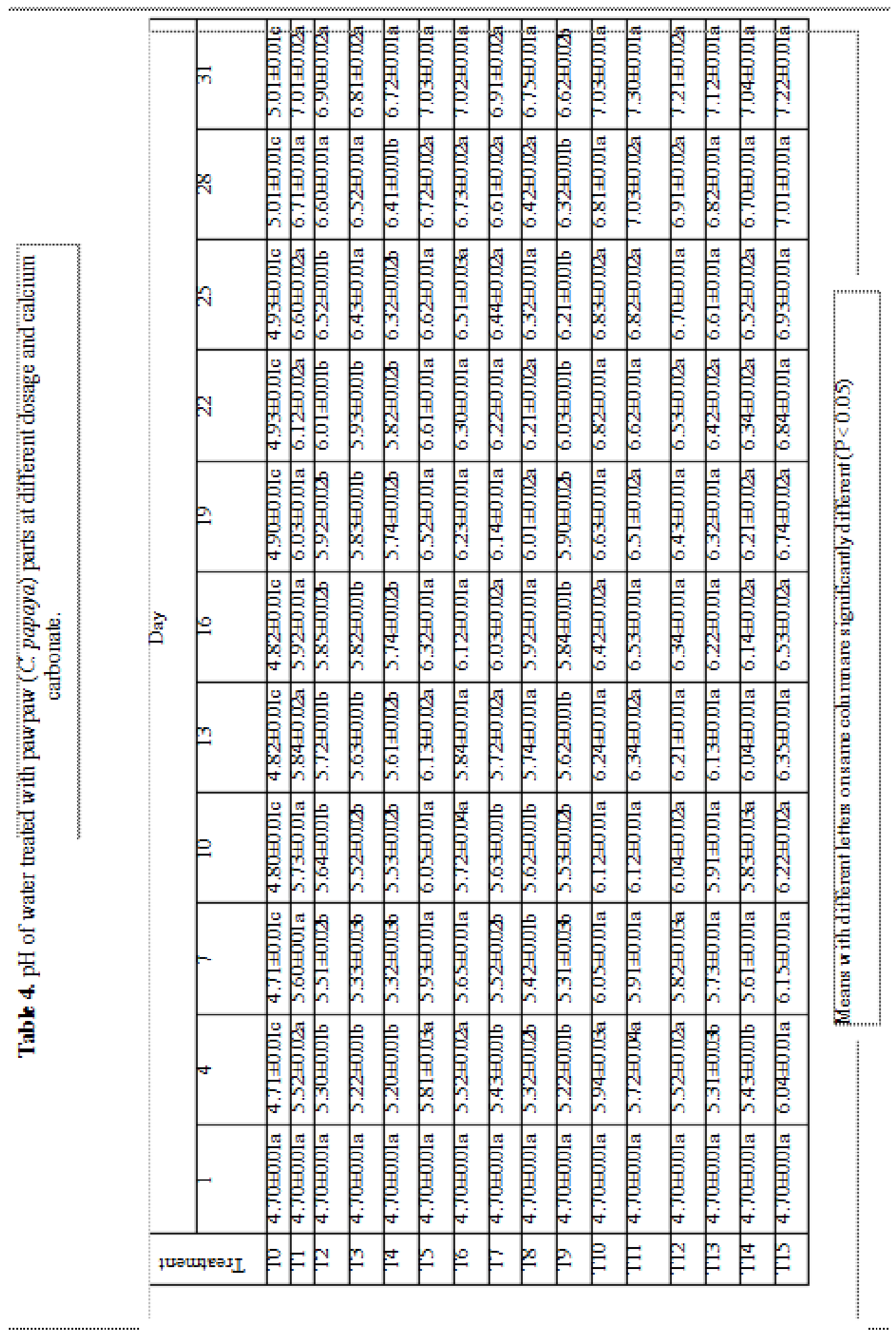


The ash content of the pawpaw leaves could be the possible reason for this observation. Munguti et al. (2006) reported $154 \pm 1.2 \mathrm{~g} / \mathrm{kg}$ DM of ash in pawpaw leaves.

For G2 treatments, similar trend was observed except that from Day 13 there were no significant differences $(\mathrm{P}>0.05)$ between DL, FL, DS and CA (Fig.3). This indicated that the buffer potency of these treatment were similar from Day 13. In the G3 treatments, no significant differences $(\mathrm{P}>0.05)$ were recorded from Day 7 (Fig. 4). It could be said that the buffer efficiency of DL, FL, DS, FS and CA were similar.

The $\mathrm{pH}$ of the experimental water changed faster (in less days) in T5, T10 and T15 with increase dosage of buffer material (CA). Similar trends were also recorded in the other treatments (DL, FL, DS and FS). In all the treatments groups, CA caused ten times change in $\mathrm{pH}$ value within four days of the experiment. This could be due to the large surface area (powdered form) of the calcium carbonate. The pawpaw leaves and stem (dried and fresh) were uncrushed (one piece) thus the gradual increases in the $\mathrm{pH}$ values. Viveen et al. (1986) reported that the efficiency of liming will decrease with increasing particle size of the liming material thus the present observation. However, T15 water ( $\mathrm{pH} 6.50)$ on Day 13 cannot be used for fish production until it is at least 14 days (two weeks) (Viveen et al., 1986). Within two weeks of treatment $\mathrm{CaCO}_{3}$ is toxic to fish thus DL, FL, DS and FL are better than CA on Day 13. The dosage (12 g) of buffer materials in G3 was adequate (Viveen et al., 1986) hence the increased $\mathrm{pH}$. The dosages of buffer materials (in all treatments) were okay based Viveen et al. (1986) that stated that 'if the selected rate of liming materials is adequate, $\mathrm{pH}$ will be above 6.5 after 2 to 4 weeks'. Therefore, the chosen rates of liming materials in this study were okay to raise $\mathrm{pH}$ of 4.7 to 6.5 . The recorded $\mathrm{pH}$ values between $6.41 \pm 0.01$ (T4) and $7.03 \pm 0.02$ (T11) on Day 28 were within the acceptable range of 6.5-9.0 recommended by SRAC (1992). This indicated that all the organic buffer agents were suitable for buffering acidic water for fish production.

The recorded temperature values in all the treatments were within the acceptable range for fish production (Boyd, 1981). It ranged between $26.2 \pm 0.02$ and $26.5 \pm 0.02$ (Table 5). Dissolved oxygen (DO) significantly increased as $\mathrm{pH}$ significantly increased between the three groups of treatments $(\mathrm{P}>0.05)$ (Table 6). The DO ranged from $3.5 \pm 0.63 \mathrm{mg} / \mathrm{L}$ (Day 1$)$ to $15 \pm 0.37 \mathrm{mg} / \mathrm{L}$ (Day 31) in all the treatment groups. The observed DO values were within the acceptable range for fish production according to Boyd (1981). This prevented the process of nitrification. Nitrification tends to have a slight tendency to acidify water as well as removing the buffering capacity or hardness of water (FishDoc, 2010)). It depletes DO concentration in water. The nitrifying bacteria (Nitrosomonas and Nitrobacter) use DO for nitrification of ammonia to nitrate (The Water Planet Company, 2010). In addition, dissolved oxygen prevents denitrification of nitrate to nitrogen gas by facultative heterotrophic bacteria. Denitrification occurs when oxygen levels are depleted and nitrate becomes the primary oxygen source for microorganisms (anoxic condition, less than $0.5 \mathrm{mg} / \mathrm{L}$ or $0.2 \mathrm{mg} / \mathrm{L}$ ).

The acceptable DO value of the experimental water from the beginning of the experiment could have contributed to the observed increases in the $\mathrm{pH}$ with day. Furthermore, diffusion of air (containing oxygen) might be a possible reason for the increases of water $\mathrm{pH}$ in all the treatments. Alkalinity is measured by the amount of acid (hydrogen ion) water can absorb (buffer) before achieving a designated $\mathrm{pH}$ (SRAC, 1992). Total alkalinity indicates capacity to neutralize acidity. It consists of carbonate, bicarbonate and hydroxide. It possesses buffering capacity against acidity and alkalinity (Aquacare 2000.3 Para test). It is an important factor that causes the $\mathrm{pH}$ value not to fluctuate. If it is low, the $\mathrm{pH}$ value is low. In G1, G2 and G3 treatments, total alkalinity was between $17 \pm 2.00 \mathrm{mg} / \mathrm{L}$ and $85 \pm 4.00 \mathrm{mg} / \mathrm{L}$ (Table 7). It increased with increased $\mathrm{pH}$. The possible reason for 
increased alkalinity in all the treatments could be attributed to increased $\mathrm{pH}$. The initial value of total alkalinity recorded in this study indicated that no base (carbonate, bicarbonate hydroxides, phosphates berates) was present in the water. Acidic ground or well water has little or no alkalinity (Wurts and Durborow, 1992) as observed in this study. The lower $\mathrm{pH}$ of borehole water (underground) is due to high carbon dioxide $\left(\mathrm{CO}_{2}\right)$ concentrations and low dissolved oxygen concentration. $\mathrm{CO}_{2}$ is high because bacterial processes in the soils and various underground particulate mineral formations through which water moves. A desirable range of total alkalinity

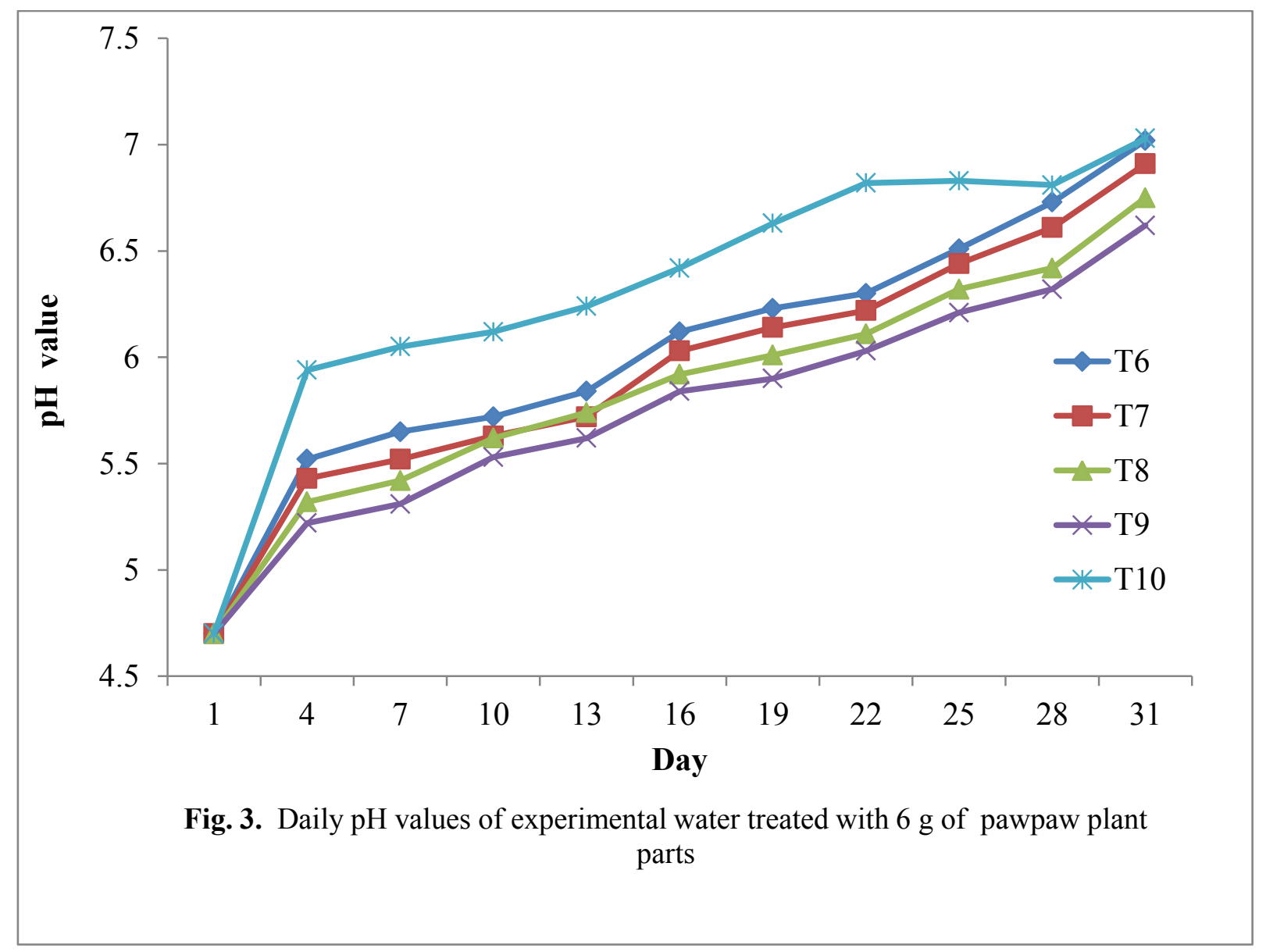

The recorded temperature values in all the treatments were within the acceptable range for fish production (Boyd, 1981). It ranged between $26.2 \pm 0.02$ and $26.5 \pm 0.02$ (Table 5). Dissolved oxygen (DO) significantly increased as $\mathrm{pH}$ significantly increased between the three groups of treatments $(\mathrm{P}>0.05)$ (Table 6). The DO ranged from $3.5 \pm 0.63 \mathrm{mg} / \mathrm{L}$ (Day 1 ) to $15 \pm 0.37 \mathrm{mg} / \mathrm{L}$ (Day 31) in all the treatment groups. The observed DO values were within the acceptable range for fish production according to Boyd (1981).

This prevented the process of nitrification. Nitrification tends to have a slight tendency to acidify water as well as removing the buffering capacity or hardness of water (FishDoc, 2010)). It depletes DO concentration in water.

The nitrifying bacteria (Nitrosomonas and Nitrobacter) use DO for nitrification of ammonia to nitrate (The Water Planet Company, 2010). In addition, dissolved oxygen prevents denitrification of nitrate to nitrogen gas by facultative heterotrophic bacteria. 
Denitrification occurs when oxygen levels are depleted and nitrate becomes the primary oxygen source for microorganisms (anoxic condition, less than $0.5 \mathrm{mg} / \mathrm{L}$ or $0.2 \mathrm{mg} / \mathrm{L}$ ).

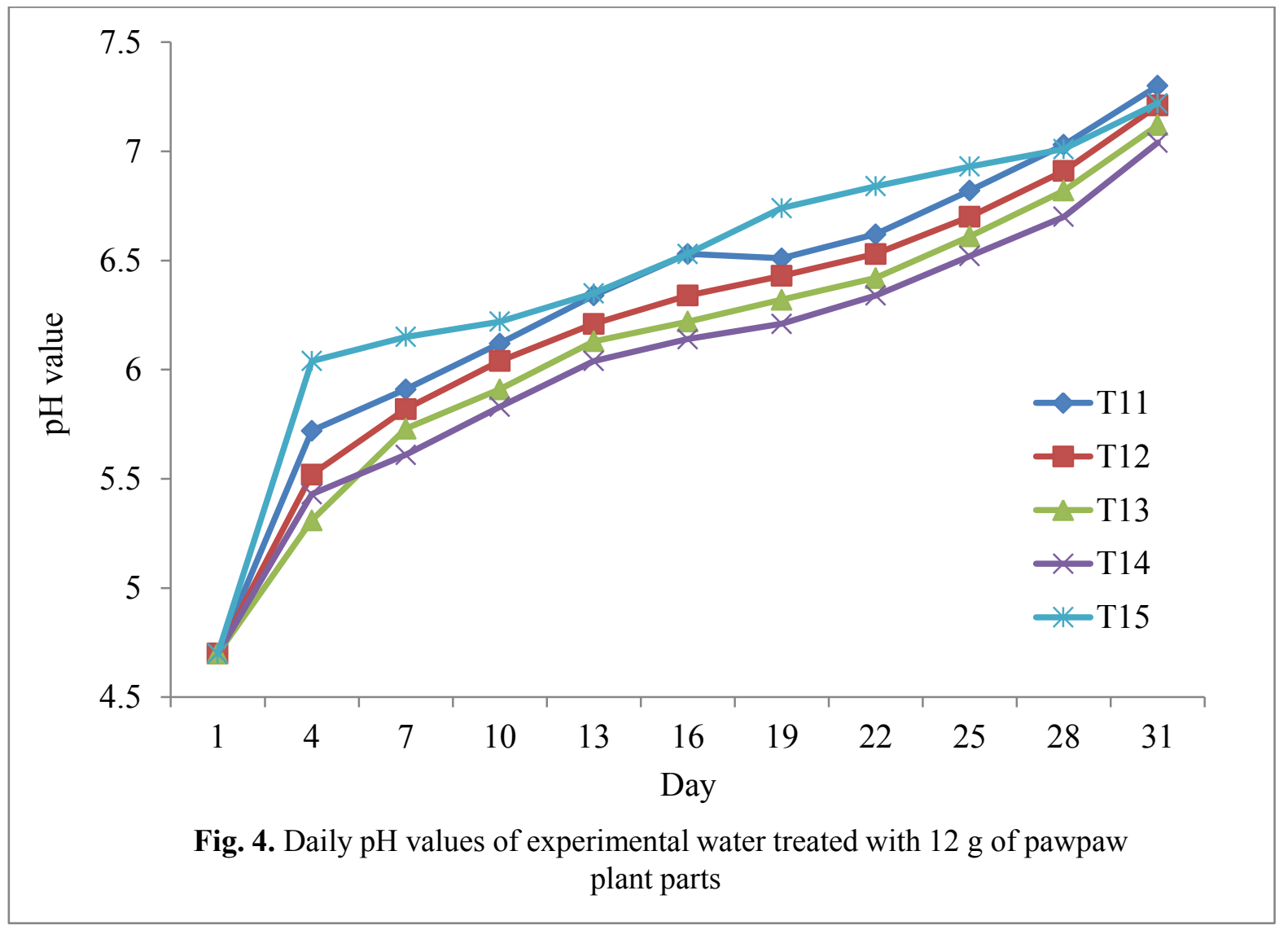

The acceptable DO value of the experimental water from the beginning of the experiment could have contributed to the observed increases in the $\mathrm{pH}$ with day. Furthermore, diffusion of air (containing oxygen) might be a possible reason for the increases of water $\mathrm{pH}$ in all the treatments. Alkalinity is measured by the amount of acid (hydrogen ion) water can absorb (buffer) before achieving a designated $\mathrm{pH}$ (SRAC, 1992). Total alkalinity indicates capacity to neutralize acidity. It consists of carbonate, bicarbonate and hydroxide. It possesses buffering capacity against acidity and alkalinity (Aquacare 2000.3 Para test). It is an important factor that causes the $\mathrm{pH}$ value not to fluctuate. If it is low, the $\mathrm{pH}$ value is low. In G1, G2 and G3 treatments, total alkalinity was between $17 \pm 2.00 \mathrm{mg} / \mathrm{L}$ and $85 \pm 4.00 \mathrm{mg} / \mathrm{L}$ (Table 7). It increased with increased $\mathrm{pH}$. The possible reason for increased alkalinity in all the treatments could be attributed to increased $\mathrm{pH}$. The initial value of total alkalinity recorded in this study indicated that no base (carbonate, bicarbonate hydroxides, phosphates berates) was present in the water. Acidic ground or well water has little or no alkalinity (Wurts and Durborow, 1992) as observed in this study. The lower $\mathrm{pH}$ of borehole water (underground) is due to high carbon dioxide $\left(\mathrm{CO}_{2}\right)$ concentrations and low dissolved oxygen concentration. $\mathrm{CO}_{2}$ is high because bacterial processes in the soils and various underground particulate mineral formations through which water moves. A desirable range of total alkalinity for fish culture is between 75 and $200 \mathrm{mg} / \mathrm{L}\left(\mathrm{CaCO}_{3}\right)(\mathrm{SRAC}, 1992)$. 


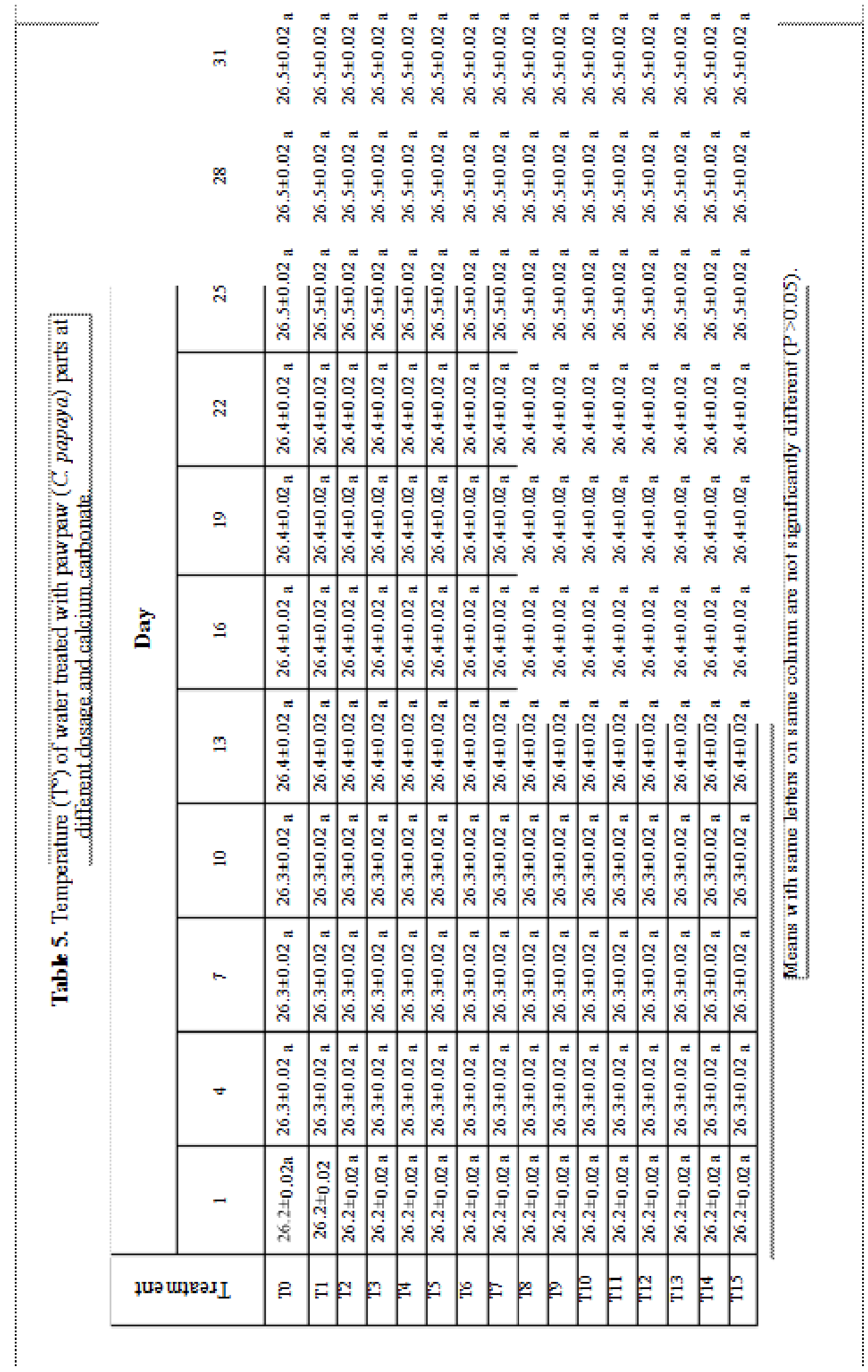




\begin{tabular}{|c|c|c|c|c|c|c|c|c|c|c|c|c|c|c|c|c|c|c|c|}
\hline \multirow{12}{*}{ 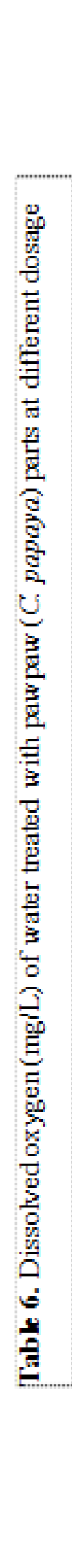 } & & $\vec{m}$ & $\begin{array}{l}8 \\
8 \\
8 \\
8\end{array}$ & 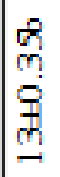 & 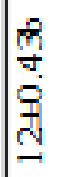 & 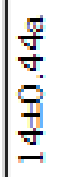 & 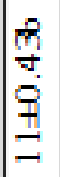 & 舀 & 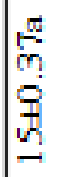 & 角 & 跑 & 啇 & 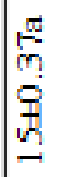 & 要 & 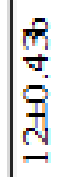 & 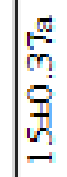 & 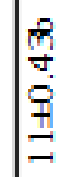 & בִn & \\
\hline & & $\stackrel{\infty}{\sim}$ & $\begin{array}{l}8 \\
8 \\
8 \\
8\end{array}$ & 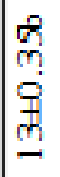 & 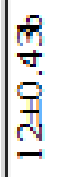 & 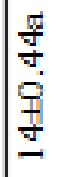 & 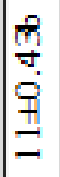 & 息 & 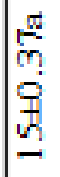 & 角 & 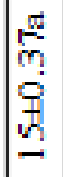 & 商 & 息 & 离 & 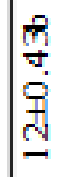 & חִ & 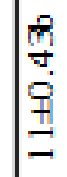 & $\frac{n}{m}$ & \\
\hline & & $\stackrel{\mathrm{N}}{2}$ & $\begin{array}{l}\stackrel{8}{6} \\
\stackrel{6}{8} \\
8\end{array}$ & 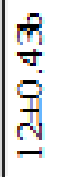 & 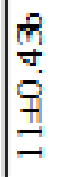 & 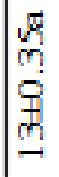 & $\begin{array}{l}8 \\
\stackrel{8}{0} \\
8 \\
0\end{array}$ & 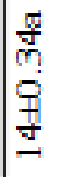 & 㝵 & 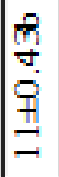 & 㞼 & 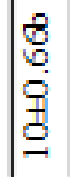 & 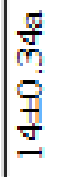 & 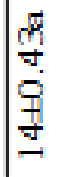 & 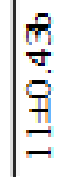 & 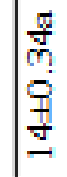 & 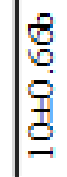 & 濷 & \\
\hline & & ঠে & $\begin{array}{l}\stackrel{6}{\circ} \\
\stackrel{8}{8}\end{array}$ & 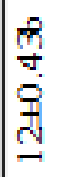 & 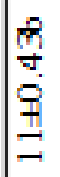 & 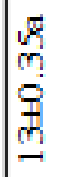 & $\begin{array}{l}8 \\
\stackrel{8}{8} \\
\stackrel{8}{0} \\
0\end{array}$ & 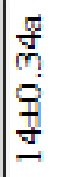 & 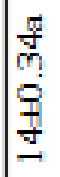 & 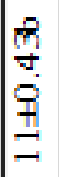 & 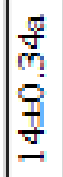 & 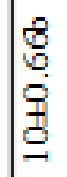 & 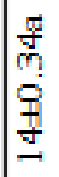 & 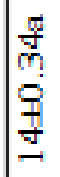 & 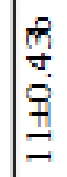 & 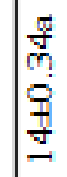 & 恖 & 丞 & $\stackrel{\text { }}{\mathrm{E}}$ \\
\hline & & $\stackrel{9}{2}$ & $\begin{array}{l}\stackrel{8}{8} \\
\stackrel{8}{8} \\
\infty\end{array}$ & 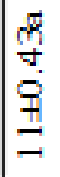 & 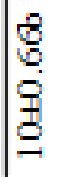 & 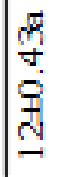 & 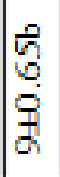 & 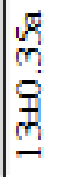 & 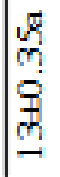 & $\begin{array}{l}8 \\
0 \\
9 \\
0\end{array}$ & 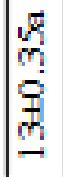 & 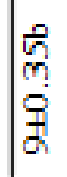 & 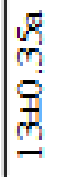 & 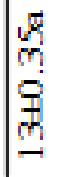 & 兑 & 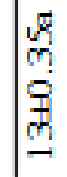 & 角 & 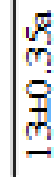 & 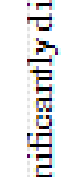 \\
\hline & & 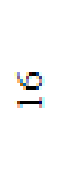 & $\begin{array}{l}\stackrel{8}{8} \\
\stackrel{8}{8} \\
\infty\end{array}$ & 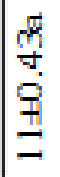 & $\begin{array}{l}8 \\
8 \\
8 \\
8\end{array}$ & 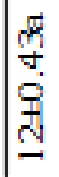 & 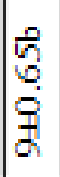 & 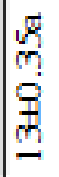 & 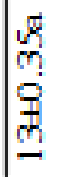 & \begin{tabular}{l}
8 \\
$\stackrel{8}{8}$ \\
$\stackrel{8}{8}$ \\
\hdashline
\end{tabular} & 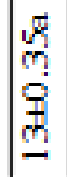 & 战 & 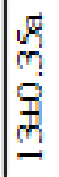 & 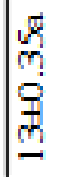 & 莫 & 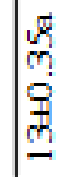 & 号 & 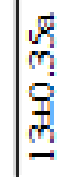 & \\
\hline & & $\stackrel{m}{-}$ & 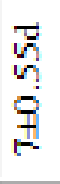 & $\begin{array}{l}\mathscr{B} \\
\stackrel{8}{0} \\
\stackrel{8}{0} \\
.\end{array}$ & 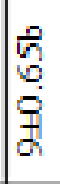 & 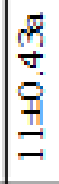 & \begin{tabular}{l}
$\mathscr{8}$ \\
$\stackrel{8}{8}$ \\
\hdashline \\
$\infty$
\end{tabular} & 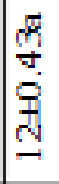 & 泾 & 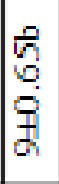 & 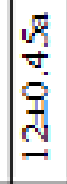 & 追 & 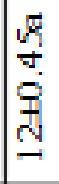 & 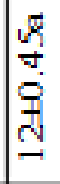 & 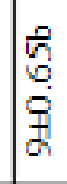 & 敢 & 追 & 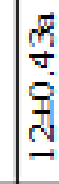 & \\
\hline & & $\cong$ & 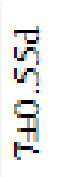 & 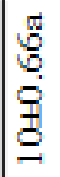 & 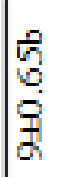 & 离 & $\begin{array}{l}\stackrel{8}{8} \\
\stackrel{8}{8} \\
\not\end{array}$ & 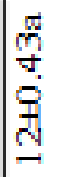 & 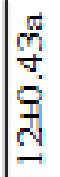 & 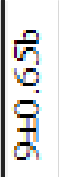 & 哭 & 兽 & 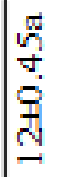 & 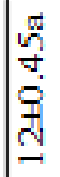 & 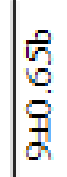 & 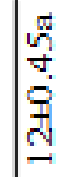 & 追 & 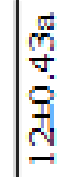 & $\frac{\bar{g}}{\bar{g}}$ \\
\hline & & $r$ & 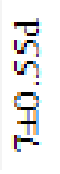 & $\begin{array}{l}8 \\
8 \\
8 \\
8\end{array}$ & 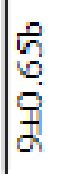 & 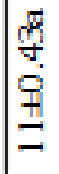 & \begin{tabular}{l}
$\stackrel{0}{8}$ \\
$\stackrel{0}{8}$ \\
\hdashline
\end{tabular} & 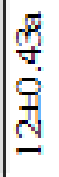 & 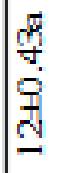 & 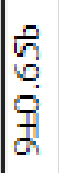 & 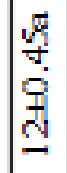 & $\mid \begin{array}{l}\mathscr{8} \\
\stackrel{8}{8} \\
\stackrel{8}{8}\end{array}$ & 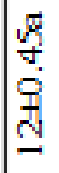 & 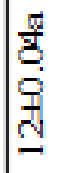 & 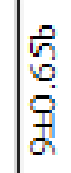 & 氶 & 兽 & 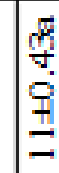 & E \\
\hline & & $\nabla$ & $\begin{array}{l}\overrightarrow{8} \\
\stackrel{8}{8} \\
8\end{array}$ & 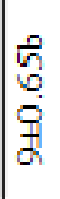 & $\begin{array}{l}80 \\
\stackrel{8}{0} \\
\stackrel{8}{0}\end{array}$ & $\begin{array}{l}\stackrel{0}{0} \\
\stackrel{0}{0} \\
\stackrel{8}{8} \\
ٍ\end{array}$ & 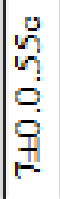 & 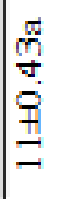 & 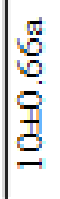 & $\begin{array}{l}8 \\
0 \\
0 \\
0\end{array}$ & 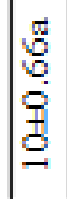 & 号 & 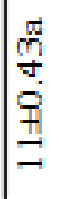 & 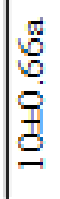 & 追 & 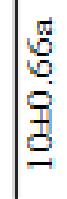 & 号 & 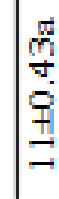 & \\
\hline & & - & 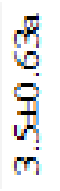 & $\begin{array}{l}\text { तु } \\
\stackrel{6}{6} \\
\stackrel{8}{8} \\
m \\
m\end{array}$ & 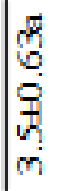 & 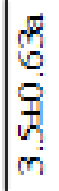 & 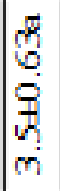 & 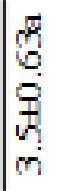 & 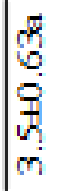 & 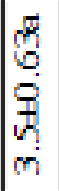 & 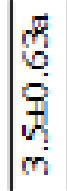 & 范 & 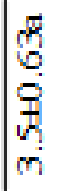 & 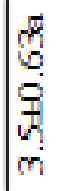 & 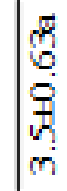 & 鷊 & 范 & 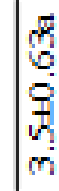 & \\
\hline & & & $\varepsilon$ & $\vec{E}$ & & & & & & & & - & & $\Rightarrow$ & & $\underline{m}$ & & $\Rightarrow$ & \\
\hline
\end{tabular}




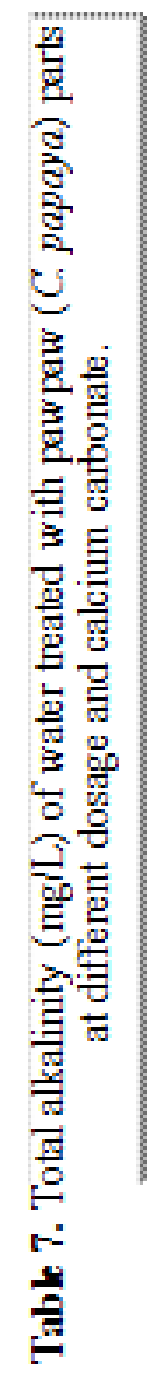

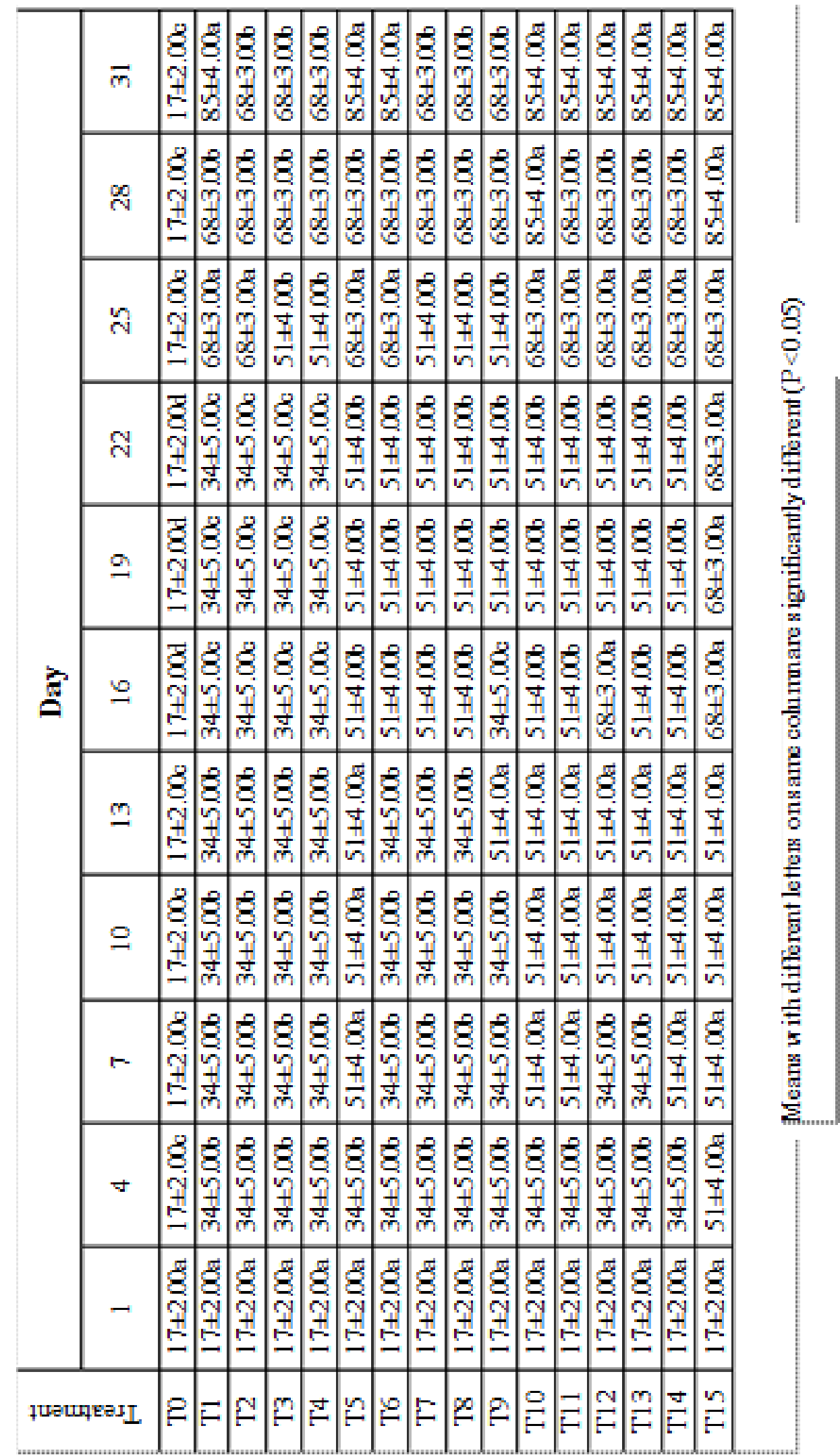




\begin{tabular}{|c|c|c|c|c|c|c|c|c|c|c|c|c|c|c|c|c|c|c|c|c|}
\hline \multirow{11}{*}{$\vec{\theta}$} & $\vec{m}$ & 8 & 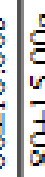 & & $\begin{array}{l}\frac{\pi}{8} \\
\frac{8}{2} \\
\frac{8}{8} \\
\infty\end{array}$ & 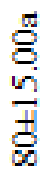 & $\begin{array}{l}\stackrel{0}{8} \\
\stackrel{8}{2} \\
\stackrel{0}{8} \\
\infty\end{array}$ & 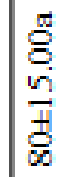 & 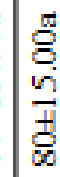 & 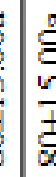 & 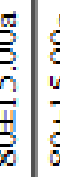 & 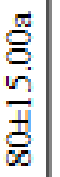 & 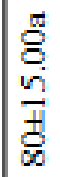 & 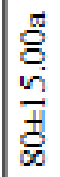 & 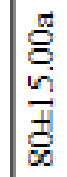 & 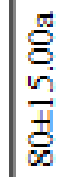 & 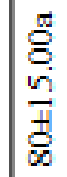 & 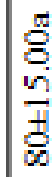 & $\frac{\mathscr{g}}{8}$ & \\
\hline & $\stackrel{\infty}{\sim}$ & 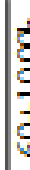 & है. & & $\begin{array}{l}\frac{8}{8} \\
\frac{8}{7} \\
\stackrel{\infty}{8}\end{array}$ & $\frac{8}{8}$ & $\begin{array}{l}8 \\
8 \\
2 \\
\\
0\end{array}$ & $\begin{array}{l}\frac{8}{8} \\
\stackrel{2}{8} \\
\bar{\infty}\end{array}$ & $\frac{8}{8}$ & 8 & & $\begin{array}{l}\stackrel{8}{8} \\
\stackrel{8}{2} \\
\vec{\infty} \\
\dot{\infty}\end{array}$ & $\begin{array}{l}\frac{8}{8} \\
2 \\
\bar{\infty} \\
\dot{\infty}\end{array}$ & 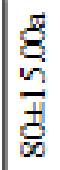 & 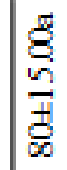 & $\begin{array}{l}\frac{8}{8} \\
\frac{m}{8} \\
\dot{\infty}\end{array}$ & $\begin{array}{l}\overrightarrow{8} \\
\frac{8}{n} \\
\\
\infty\end{array}$ & 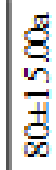 & $\frac{8}{\frac{8}{0}}$ & \\
\hline & ๙ิ & 8 & 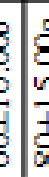 & 8 & 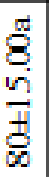 & 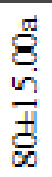 & 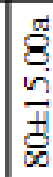 & $\begin{array}{l}\stackrel{g}{8} \\
\text { v } \\
\dot{0} \\
\dot{\infty}\end{array}$ & $\frac{8}{8}$ & 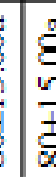 & $\frac{8}{8}$ & 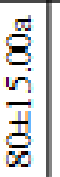 & $\begin{array}{l}\frac{\pi}{8} \\
\frac{1}{2} \\
\\
\dot{\infty}\end{array}$ & 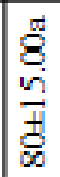 & 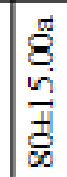 & 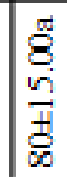 & 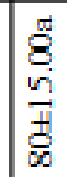 & 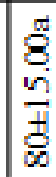 & $\frac{g}{8}$ & $\dot{8}$ \\
\hline & ㄱ & 8 & 8 & & $\begin{array}{l}\frac{\pi}{8} \\
\frac{\vec{d}}{\overrightarrow{0}} \\
\vec{\infty}\end{array}$ & 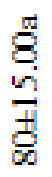 & 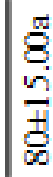 & 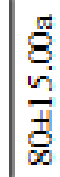 & $\begin{array}{c}8 \\
8 \\
\\
\infty\end{array}$ & 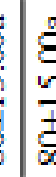 & $\begin{array}{l}8 \\
\frac{8}{8} \\
\frac{8}{8}\end{array}$ & 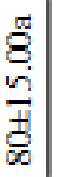 & $\begin{array}{l}\frac{\pi}{8} \\
\frac{1}{2} \\
\dot{0} \\
\dot{\infty}\end{array}$ & 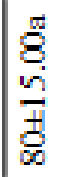 & 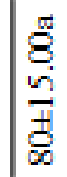 & 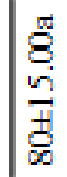 & 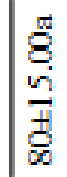 & $\begin{array}{l}\stackrel{0}{8} \\
\frac{\sigma}{2} \\
\dot{\infty} \\
\dot{\infty}\end{array}$ & $\frac{8}{8}$ & 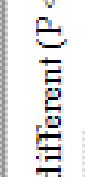 \\
\hline & $\Omega$ & 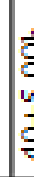 & 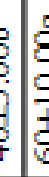 & & $\begin{array}{l}\stackrel{6}{8} \\
\stackrel{8}{\circ} \\
\frac{10}{6}\end{array}$ & 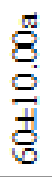 & $\frac{g}{8}$. & $\begin{array}{l}8 \\
8 \\
0 \\
8 \\
8\end{array}$ & $\frac{8}{8}$ & 8 & 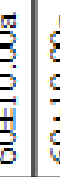 & 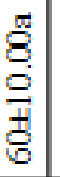 & 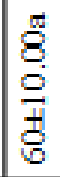 & 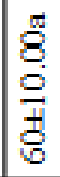 & 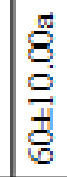 & 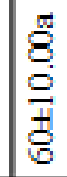 & 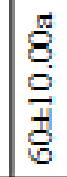 & $\begin{array}{l}\frac{\pi}{8} \\
\frac{n}{0} \\
\dot{0}\end{array}$ & $\frac{8}{8}$ & 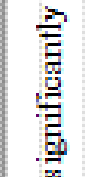 \\
\hline & 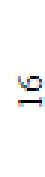 & 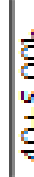 & 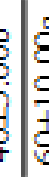 & & $\begin{array}{l}\stackrel{6}{8} \\
\stackrel{8}{\circ} \\
\stackrel{\overrightarrow{0}}{0}\end{array}$ & $\frac{g}{8}$ & $\frac{8}{8}$. & $\frac{8}{8}$. & $\frac{8}{8}$ & 8 & $\begin{array}{l}8 \\
\frac{8}{8} \\
\frac{8}{6}\end{array}$ & $\begin{array}{l}\stackrel{0}{8} \\
\stackrel{8}{g} \\
\frac{1}{8}\end{array}$ & $\begin{array}{l}\frac{\pi}{8} \\
8 \\
\frac{8}{8} \\
\delta\end{array}$ & $\begin{array}{l}\frac{\pi}{8} \\
8 \\
\frac{8}{8} \\
\delta\end{array}$ & 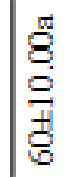 & 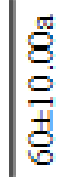 & 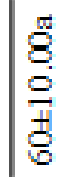 & $\begin{array}{l}\frac{g}{8} \\
8 \\
8 \\
8\end{array}$ & $\frac{g}{g}$ & $\frac{\pi}{5}$ \\
\hline & $m$ & 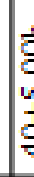 & 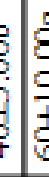 & & $\begin{array}{l}\frac{\pi}{8} \\
\frac{8}{8} \\
\frac{1}{8}\end{array}$ & $\begin{array}{l}\stackrel{\pi}{8} \\
\stackrel{8}{0} \\
\stackrel{H}{0}\end{array}$ & 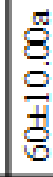 & $\frac{\frac{\pi}{8}}{\circ} \frac{.}{8}$ & $\frac{8}{8}$ & 8 & $\frac{8}{8}$ & $\begin{array}{l}\stackrel{0}{8} \\
\stackrel{8}{\circ} \\
\frac{1}{8}\end{array}$ & 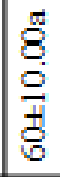 & 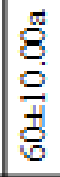 & $\frac{\stackrel{g}{8}}{\circ}$ & $\frac{\stackrel{g}{8}}{\circ}$ & $\frac{\stackrel{g}{8}}{\circ}$ & 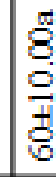 & $\frac{8}{8}$ & 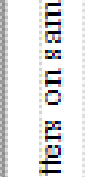 \\
\hline & $\subseteq$ & 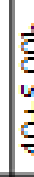 & 8 & & $\begin{array}{l}\stackrel{6}{8} \\
\stackrel{8}{\circ} \\
\frac{10}{6}\end{array}$ & 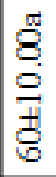 & 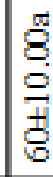 & $\mid \begin{array}{l}8 \\
8 \\
g \\
\end{array}$ & $\frac{8}{8}$ & 8 & $\begin{array}{c}8 \\
8 \\
8 \\
8\end{array}$ & $\begin{array}{l}\stackrel{6}{8} \\
\stackrel{8}{\circ} \\
\stackrel{t}{8} \\
8\end{array}$ & 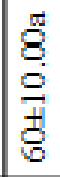 & 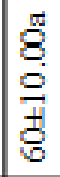 & $\frac{\stackrel{g}{8}}{\circ}$ & 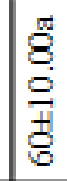 & 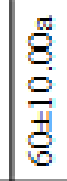 & $\begin{array}{l}8 \\
8 \\
0 \\
8 \\
8\end{array}$ & $\frac{g}{8}$ & ह \\
\hline & 1 & 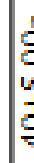 & 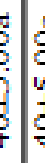 & & 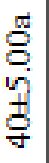 & $\begin{array}{l}\frac{\pi}{8} \\
\dot{8} \\
\text { 웅 }\end{array}$ & $\begin{array}{l}\frac{\pi}{8} \\
\text { v. } \\
\text { f }\end{array}$ & $\begin{array}{l}\stackrel{g}{8} \\
\text { vi } \\
\text { Oे }\end{array}$ & $\begin{array}{l}8 \\
8 \\
8\end{array}$ & $\frac{9}{8}$ & 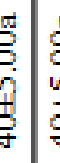 & $\begin{array}{l}\stackrel{0}{8} \\
\dot{8} \\
8 \\
8\end{array}$ & 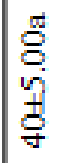 & 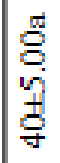 & 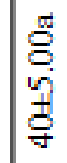 & 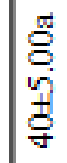 & 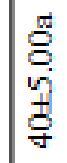 & $\begin{array}{l}\stackrel{g}{8} \\
v \\
8 \\
\text { f }\end{array}$ & 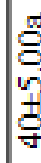 & 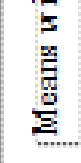 \\
\hline & $\nabla$ & 8 & & & $\begin{array}{l}\stackrel{6}{8} \\
\stackrel{8}{0} \\
\stackrel{8}{8}\end{array}$ & 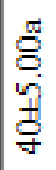 & 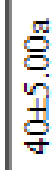 & $\begin{array}{l}\frac{\pi}{8} \\
\text { v } \\
\text { f }\end{array}$ & $\begin{array}{l}0 \\
5 \\
\end{array}$ & $\frac{8}{8}$ & $\begin{array}{l}8 \\
8 \\
8\end{array}$ & $\begin{array}{l}\stackrel{c}{8} \\
\dot{8} \\
\dot{8} \\
\stackrel{8}{8}\end{array}$ & $\begin{array}{l}\frac{\pi}{8} \\
\dot{0} \\
\text { ô }\end{array}$ & 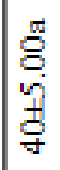 & 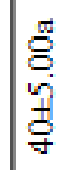 & 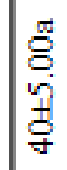 & 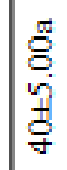 & $\begin{array}{l}\stackrel{g}{8} \\
5 \\
8 \\
8\end{array}$ & 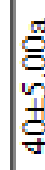 & \\
\hline & - & 8 & & t. & 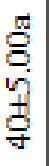 & 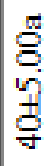 & $\begin{array}{l}\stackrel{5}{8} \\
\text { s. } \\
0 \\
\text { f }\end{array}$ & $\begin{array}{l}\frac{g}{8} \\
\text { vi } \\
\text { Oे }\end{array}$ & $\frac{g}{8}$ & 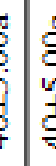 & $\begin{array}{l}8 \\
8 \\
8\end{array}$ & $\begin{array}{l}\stackrel{0}{8} \\
\stackrel{8}{0} \\
\stackrel{8}{8}\end{array}$ & 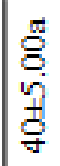 & 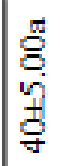 & 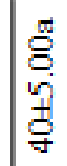 & 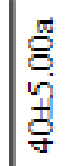 & 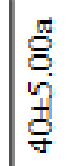 & 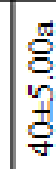 & 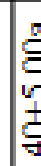 & \\
\hline & & & & & & $m$ & & & & & & $\infty$ & 2 & $\frac{\varrho}{E}$ & $\vec{E}$ & $\stackrel{\mathcal{N}}{E}$ & $\frac{m}{2}$ & & $=$ & \\
\hline
\end{tabular}


The observed range of $68.00 \pm 3.00 \mathrm{mg} / \mathrm{L}$ (T1 to $\mathrm{T} 14$ ) to $85.00 \pm 4.00 \mathrm{mg} / \mathrm{L}$ (T15) on Day 28 (Table 7) was within the acceptable range for fish production. At the end of the study, calcium ranged from $40 \pm 5.00$ to $80 \pm 15.00 \mathrm{mg} / \mathrm{L}$ in all the treatment groups (Table 8). Calcium is essential in the biological processes of fish (bone and scale formation, blood clotting and other metabolic reactions). It is the most important environmental, divalent salt in fish culture. The recorded concentration in the treated water was within the recommended range of free calcium in culture waters of 25 to $100 \mathrm{mg} / \mathrm{L}$ ( 63 to $250 \mathrm{mg} / \mathrm{L}$ calcium carbonate hardness). Environmental calcium is required to reduce the loss of sodium and potassium from the fish body fluids/blood. Sodium and potassium are the most important salts in fish blood, normal heart nerve and muscle function. It is also needed to help reabsorb these lost salts to the environment. The increased calcium concentrations (from $40 \pm 5.00 \mathrm{mg} / \mathrm{L}$ to 80 $\pm 15.00 \mathrm{mg} / \mathrm{L}$ ) in of the treated water could be attributed to the calcium content of the pawpaw leaves and stem. Nwofia et al. (2012) reported that the leaves of five morphotypes of pawpaw contain $267.2 \mathrm{mg} / 100 \mathrm{~g}$ and $366.70 \mathrm{mg} / 100 \mathrm{~g}$ of calcium, and $1.43 \%$ and $2.25 \% \mathrm{ash}$. The initial $(40 \pm 5.00 \mathrm{mg} / \mathrm{L})$ acceptable calcium concentration in the borehole could be that the soil contains some amount of natural limestone. The observed high calcium levels in T5, T10 and T15 might be linked to the added calcium carbonate (chemical substance). Agricultural limestone can be used to increase calcium concentrations (and carbonate - bicarbonate alkalinity) in areas with acidic waters or soils.

\section{CONCLUSION/RECOMMENDATION}

The advocacy for organic aquaculture is gaining ground in the present world, it is therefore reasonable to consider dried leaves, fresh leaves, dried stem and fresh stem of pawpaw plant as organic buffers. These forms of pawpaw plant buffer water with low $\mathrm{pH}$ as $\mathrm{CaCO}_{3}$ does. This study therefore suggests dried and fresh leaves and stem of pawpaw plant (at least $2.4 \mathrm{~g}$ per 25-litre tank, 20-litres filled with water) for at least sixteen (16) days as an alternative buffering agents for acidic water for fish production in Port Harcourt and other parts of the world with low water $\mathrm{pH}$ problem. However, the present study recommends that dried and fresh pawpaw plant parts in powdered, granulated and milled forms to be tested on acidic water to see if $\mathrm{pH}$ of 6.5 can be obtained before sixteen days of treatment. The use of pawpaw plant parts (especially dried and fresh leaves) as organic buffers for safe and healthy fish production is free of cost and can be used by fish farmers for better profitability.

\section{References}

[1] Bhat G. P., Surolia N., American Journal of Tropica Medicine and Hygiene 65(4) (2001) 304-308.

[2] Clean Water Team [CWT) (2004). pH fact sheet, FS-3.1.4.0 (pH). In: The Clean Water Team Guidance Compendium for Watershed Monitoring and Assessment, Version 2.0. Division of Water Quality, California State Water Resources Control Board (SWRCB), Sacramento, CA.

[3] Davies R. M., U. S. Mohammed, Singapore Journal of Scientific Research 1(3) (2011) 253-263. 
[4] Doughari J. H., Elmahmood A. M., Manzara S. (2007). Studies on the antibacterial activity of root extracts of Carica papaya L. African Journal of Microbiology Research pp. 037-041. Available online http://www.academicjournals.org/ajmr.

[5] FishDoc. (2010). Fish health and pH. Retrieved from http://www.fishdoc.co.uk/water/pH.html on $26^{\text {th }}$ June, 2010.

[6] Garba S., Okeniyi S. O., Journal of Microbiology and Antimicrobials 4(3) (2012) 60-63.

[7] International Joint Commission (IJC) (1977). New and revised specific water quality objectives. Vol 11. Great Lakes Water Quality Board Report.

[8] Munguti J. M., Liti D. M., Waidbacher H., Straif. M., Zollitsch W., Journal of Agricultural Research 57(3) (2006) 131-141.

[9] Nwofia G. E., Ojimelukwe P., Eji C., International Journal of Medicinal and Aromatic Plants 2(1) (2012) 200-206.

[10] Okpaku A. T. (2011). Status of catfish farming in selected Local Government Areas in Rivers State, Nigeria: prospects and problems. B.Sc. Project (Unpublished). Rivers State University of Science and Technology, Port Harcourt, Nigeria. 52 pp.

[11] Oloyede O. I., Pakistan Journal of Nutrition 4(6) (2005) 379-381.

[12] Otsuki N., Dang N. H., Kumagai E., Kondo A., Iwata S., Monmoto C., J. Ethnopharmacol 127 (2010) 760-767.

[13] SAS (2003). Statistical Analysis System. User's Guide SAS/STA-t Version. 8th Edn., SAS, Institute, Inc. Cary, N. C., US.

[14] Srikanth G. S., Manohar B., Kavitha C. N. and Bhanoji R. M. E., Research Journal of Pharmaceutical, Biological and Chemical Sciences 1(2) (2010) 59-65.

[15] United Nations (1992). The Convention on Biological Diversity.

[16] Viveen W. J. A R., C. J. J. Richter, P. G. W. J. van Oordt, J. A. L. Janseen, E. A. Huisman (1986). Practical Manual for the Culture of African Catfish (Clarias gariepinus). Directorate General for International Technical Corporation, The Hague, The Netherlands, Pages: 107.

[17] Water Research Commission (2010). A manual for rural Freshwater Aquaculture. Available online www.dbsa.org/.....TT\%20463\%20=P.

[18] Wurts W. A., Durborow R. M. (1992). Interactions of $\mathrm{pH}$, carbon dioxide, alkalinity And hardness in fish ponds. Southern Regional Aquaculture Centre, Publication No.454. 